\title{
In vitro response of date palm (Phoenix dactylifera L.) inflorescence explants to high 2iP and 2,4-D concentrations
}

\author{
Juliana Martins Ribeiro*1, Silvio Lopes Teixeira ${ }^{1}$, Joselita Cardoso de Souza ${ }^{2}$, Brenda Lima Ribeiro ${ }^{2}$, \\ Antônio Bruno Nunes Oliveira ${ }^{2}$, Thiago Francisco de Souza Carneiro Neto ${ }^{2}$, Lucas Silva Rios ${ }^{2}$ e Reivandson \\ dos Santos Vieira ${ }^{2}$
}

\author{
${ }^{1}$ Biotechnology Laboratory, Brazilian Corporation of Agricultural Research of the Semiarid Tropics, \\ Petrolina, PE, 56302-970, Brazil - corresponding authors \\ ${ }^{2}$ Biotechnology Laboratory, State University of Bahia, Juazeiro, BA, 48900-000, Brazil
}

Abstract

\begin{abstract}
One of the major problems related to the implementation of date palm crops in Brazil is propagation. Therefore, the aim of this study was to evaluate the possibility of using tissue culture technique for the in vitro propagation of this species. Hence, the effect of 2iP and 2,4-D on the in vitro response of date palm inflorescence tissues, related to floral bud swelling, callusing, and rhizogenesis, was evaluated. The absence of 2,4-D was more detrimental to the in vitro response of inflorescence bud explants than absence of $2 \mathrm{iP}$. In treatments without addition of 2,4-D to the culture medium, explants did not have swelling, callus or root formation. The treatment containing $150 \mathrm{mg} / \mathrm{L} \mathrm{2,4-D}$ in the presence of $1.5 \mathrm{mg} / \mathrm{L} 2 \mathrm{iP}$ initiated explant swelling, and treatments with either $100 \mathrm{mg} / \mathrm{L}$ or $150 \mathrm{mg} / \mathrm{L}$ 2,4-D, combined with $3.0 \mathrm{mg} / \mathrm{L} 2 \mathrm{iP}$, were also efficient in stimulating in vitro swelling of inflorescence buds. Rhizogenesis was induced at the highest concentrations of 2,4-D (100 and $150 \mathrm{mg} / \mathrm{L}$ ), combined with $4.5 \mathrm{mg} / \mathrm{L}$ $2 \mathrm{iP}$, and was visually more evident in the treatment containing $150 \mathrm{mg} / \mathrm{L} 2,4-\mathrm{D}+4.5 \mathrm{mg} / \mathrm{L} 2 \mathrm{iP}$. These results suggest that even higher concentrations of these two reagents might be efficient in the micropropagation of new existing date palm genotypes in the Submedium São Francisco River Valley.
\end{abstract}

Keywords: auxin, cytokinin, palm, rhizogenesis, micropropagation.

Abbreviations: 2,4-D_dichlorofenoxiacetic acid, 2iP_isopenteniladenine.

Introduction

Date palm (Phoenix dactylifera L.) is a dioecious, monocot plant species derived from the Middle East, which belongs to the Arecaceae family. Its root system is capable of penetrating down to 4 meters depth, reaching deep groundwaters. This enables its development in hot and arid regions and in several types of soil, including salinated soils, and therefore, it has good adaptation to desert climatic conditions, with high temperatures and low relative air humidity (Costa and Aloufa, 2010). It is an important palm in the economic and social life of populations of semiarid regions worldwide, producing highly nutritious, edible fruits. Several sectors in economy, mostly those related to the food industry, are interested in its exploitation (Khelil et al., 2016).

According to data from FAO (2017), the largest date palm producers in the world in 2014 were Egypt $(1,465,030$ tons), followed by Iran (1,156,996 tons) and Algeria (934,377 tons). Regarding date palm cultivated area, Iraq has the largest area, with 242,632 hectares, followed by Algeria $(165,378$ ha) and Iran (150,207 ha). Brazil imports all the date palm consumed in the country although it has regions with climatic conditions similar to those observed in the major world producers of this fruit. In 2014, it imported approximately 777 tons of date palms, of which 48 tons were fresh dates and 727 tons were dried dates. On the other hand, there was a drop in importations in 2015, totaling 604 tons, with fresh dates accounting for 25 tons and dried dates accounting for 578 tons. In 2016, these amounts increased again, reaching approximately 791 tons, with 24 tons of fresh dates and 766 tons of dried dates (FAO, 2017). Regarding amounts in Brazilian reals, Brazil spent over eight million in 2014, approximately 6 million in 2015, and approximately 7 million Brazilian reals in 2016 with the importation of dried and fresh dates, totaling more than 21 million Brazilian reals over three years (FAO, 2017).

As it is a tropical plant, requiring high temperatures and low rainfall, date palm is a promising crop for the Brazilian Northeast, as Brazil has potential both to produce all the date palm consumed in the country and to take part in the global scenario of date pam production. The beginning of date palm fruiting varies according to climate, soil conditions, plant origin (offshoots or seeds), and genotypes used. Date palm typically starts to produce fruits six to eight years after its planting. In the Northeastern Semiarid, date palms begin fruiting two to four years after planting, which represents a huge earliness and economic advantage (Simão, 1998; Ribeiro and Teixeira, 2017).

However, one of the major bottlenecks related with the implementation of date palm crops in Brazil is propagation. The propagation of the majority of the species in the 
Arecaceae family depends on seed germination and development, and it can also be propagated by offshoots or in vitro cultivation. As it is a dioecious plant, its propagation through seeds might result in descendants that do not replicate the genetic characters of the parent plant, which is undesirable when the target is to maintain fruit quality or canopy architecture (Ribeiro and Teixeira, 2017). Moreover, when plants are obtained from seeds, the ratio between female and male plants is $1: 1$ and sex can only be determined after flowering, which might take years and is not economically feasible (Simão, 1998).

In vitro propagation of date palms has been widely studied in several countries (Taha et al., 2003; Badawy et al., 2005; Eke et al., 2005; Khierallah and Bader, 2007; Othmani et al., 2009; Al-Khayri, 2010; Abul-Soade and Mahdi, 2010; Aslam et al., 2011; Eldin and Ibrahim, 2015), including those that use inflorescence segments as explants (Bhaskaran and Smith, 1992; Zayed et al., 2016; Ribeiro and Teixeira, 2017). Although it has proven to be the ideal technique for the propagation of this species, information and research about it in Brazil are either poor or nonexistent.

Considering the great potential that date palm crops represent for the Semiarid regions of the Northeast, and consequently, for Brazil as a whole, the aim of this study was to evaluate the effect of $2 \mathrm{iP}$ and 2,4-D on the in vitro response of date palm inflorescence tissues. Experiments were conducted with date palm tissues resulting from seed germination obtained by open pollination, already adapted to the environmental conditions of the Submedium São Francisco River Valley, and for which no technologies have been developed for in vitro cultivation, yet.

\section{Results and discussion}

According to the analysis of variance, a significant effect was observed in the two factors and there was interaction between both regulators using $1 \%$ of probability (Table 1 ). In the treatments with no addition of $2 \mathrm{iP}$, explant response occurred only with the presence of 2,4-D in the culture medium. A quadratic equation was obtained in which the estimated maximum point of explant response occurred when $116.76 \mathrm{mg} / \mathrm{L}$ 2,4-D was added. A linear regression was observed in the treatments with addition of $1.5 \mathrm{mg} / \mathrm{L} 2 \mathrm{iP}$ to the culture medium, and the concentration of $150 \mathrm{mg} / \mathrm{L}$ 2,4$D$ was estimated to account for inducing the highest in vitro explant response. There was a quadratic effect in treatments with addition of $3.0 \mathrm{mg} / \mathrm{L} 2 \mathrm{iP}$, and the concentration of $141.36 \mathrm{mg} / \mathrm{L}$ 2,4-D was estimated to induce the highest in vitro explant response. The regression equation of the treatment with $4.52 \mathrm{iP}$ was not significant $(\mathrm{p}>0.05)$. In this treatment, $2 \mathrm{iP}$ concentration caused explant response regardless of the 2,4 D concentration in the culture medium (Figure 1).

Figure 2 shows patterns representative of tissue response (explant swelling and rhizogenesis) in date palm inflorescence explants according to the different 2iP and 2,4D concentrations.

The absence of 2,4-D (T1, T5, T9, and T13) was more harmful to explant response of date palm inflorescences than low 2ip $(T 1, T 2, T 3$, and T4). In most treatments where there was no addition of 2,4-D to the culture medium (T1, T5, and T9), explant response was very low; it was $15 \%$ lower in the treatments containing $1.5 \mathrm{mg} / \mathrm{L}$ (T5) and $3 \mathrm{mg} / \mathrm{L}$ (T9) $2 \mathrm{iP}$. Most of the explants in the media without 2,4-D remained in their primary original form or were completely oxidized and dead. However, the addition of the lowest concentration of 2,4-D (50 $\mathrm{mg} / \mathrm{L})$ to the culture media without $2 \mathrm{iP}$ caused the in vitro explant response to increase by more than $80 \%$ (T2) and remained over $60 \%$ in the other treatments (T3 and T4) with low 2iP (Figures 1 and 2). 2,4-D is a synthetic auxin that has proven to be efficient in inducing somatic embryogenesis and organogenesis in date palms, in explants derived from shoot tips (Bhaskaran and Smith, 1992; El Hadrami et al., 1995; Zouine et al., 2007), inflorescence tissues (Bhaskaran and Smith, 1992; Zayed et al., 2016; Ribeiro and Teixeira, 2017), or offshoots (Aslam et al., 2011; Bekheet, 2013; El-Bahr et al., 2016).

Auxin 2,4-D and cytokine 2iP are growth regulators typically used to induce the formation of embryogenic callus in explants derived from offshoot meristem tips, or from inflorescence tissues of young date palms (Ribeiro and Teixeira, 2017). The treatment containing $1.5 \mathrm{mg} / \mathrm{L} 2 \mathrm{iP}$ combined with $150 \mathrm{mg} / \mathrm{L} \mathrm{2,4-D} \mathrm{(T8),} \mathrm{and} \mathrm{the} \mathrm{treatment}$ containing $3.0 \mathrm{mg} / \mathrm{L} \mathrm{2iP}$ followed by the addition of 141.36 $\mathrm{mg} / \mathrm{L}$ 2,4-D were statistically efficient in inducing explant swelling (Figure 2). Teixeira and Ribeiro (2015), evaluating the in vitro response of different date palm genotypes situated in Petrolina, $\mathrm{PE}$, and Juazeiro, BA, observed that a concentration of $3 \mathrm{mg} / \mathrm{L} 2 \mathrm{iP}$ was required to stimulate somatic embryogenesis in node segments of inflorescence. Similarly, Taha et al. (2003) and Badhawy et al. (2005) observed that the addition of $3 \mathrm{mg} / \mathrm{L} 2 \mathrm{iP}$ to the culture medium using offshoots as a source of explants induced embryogenic callus. This was also observed by Eke et al. (2005), who used meristem tip explants. However, the effects of concentrations higher than this value have not been evaluated.

Figure 2 shows that root formation began in the treatment containing $100 \mathrm{mg} / \mathrm{L} \mathrm{2,4-D} \mathrm{combined} \mathrm{with} 4.5 \mathrm{mg} / \mathrm{L} \mathrm{2iP}$ (T15), while root formation strongly benefitted from the treatment containing $150 \mathrm{mg} / \mathrm{L}$ 2,4-D combined with 4.5 $\mathrm{mg} / \mathrm{L} 2 \mathrm{iP}$ (T16). Bekheet (2013) induced the formation of sprouts by direct adventitious organogenesis from date palm offshoots when he added $5 \mathrm{mg} / \mathrm{L} 2 \mathrm{iP}$ to the culture medium. The total immersion of explants in the semi-solid culture medium also decreased explant oxidation, stimulated root formation, and anticipated tissue response to 2-4 months in date palms (Figure 2), instead of the 6-8 months required in the conventional technique, thus corroborating the results obtained by Ribeiro and Teixeira (2017).

Plants can be obtained by micropropagation via three morphogenic pathways, namely: proliferation of buds, in which multiplication occurs by the proliferation and growth of existing meristems in the plant; (direct or indirect adventitious) organogenesis, which consists in the formation of organs from non-meristem tissues; and somatic embryogenesis, which might also occur either directly or indirectly and consists of the regeneration of embryos from somatic cells (Chawla, 2004).

The induction of an in vitro development pattern, whether it is the proliferation of existing buds, the formation of callus, or the formation of new buds or roots, depends on the balance between the concentrations of auxin and cytokine added to the culture medium (Ribeiro and Teixeira, 2017; Bekheet, 2013). On the other hand, different date palm genotypes respond differently to in vitro stimulus and might need changes in reagent concentrations and in the balance between growth regulators added to the culture medium (Eshraghi et al., 2005; Ribeiro and Teixeira, 2017). 
Table 1. Analysis of variance of the mean number of explants that were stimulated in vitro according to the different concentrations of 2iP and 2,4-D and to the interaction between them. State University of Bahia (UNEB), Juazeiro, 2017.

\begin{tabular}{|c|c|c|c|c|c|}
\hline Variation causes & G. L. & S. Q. & Q. M. & $\mathrm{F}$ & $\mathrm{P}$ \\
\hline $2 \mathrm{iP}$ & 3 & 11078.438 & 3692.813 & $10.942^{*}$ & $<0.0001$ \\
\hline $2,4-D$ & 3 & 38415.938 & 12805.31 & $37.942 *$ & $<0.0001$ \\
\hline $2 \mathrm{iP} \times 2,4-\mathrm{D}$ & 9 & 13885.313 & 1542.813 & $4.5713^{*}$ & 0.0001 \\
\hline Residue & 64 & 21600 & - & - & \\
\hline Total & 79 & 84979.688 & - & - & \\
\hline
\end{tabular}

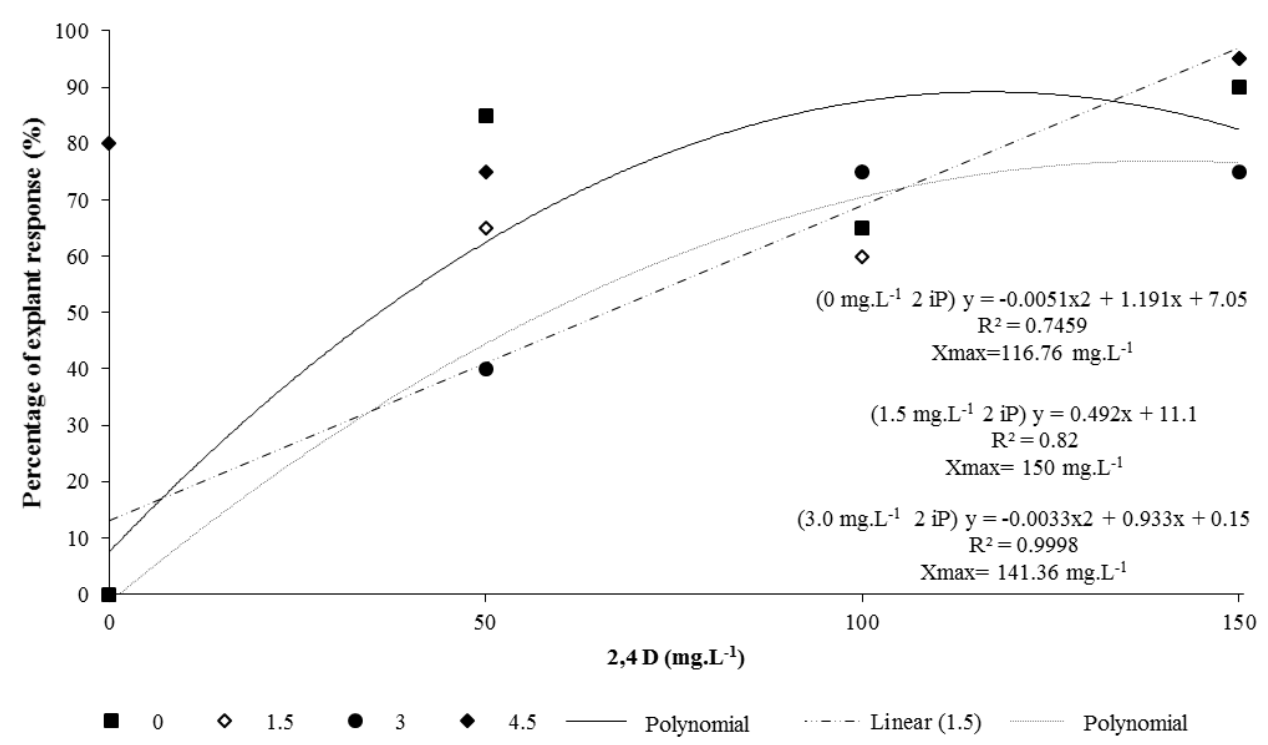

Fig 1. Date palm explant reaction in media with $2 \mathrm{iP}$ concentrations of $0,1.5$, and $3 \mathrm{mg} / \mathrm{L}$ and different 2,4-D concentrations.

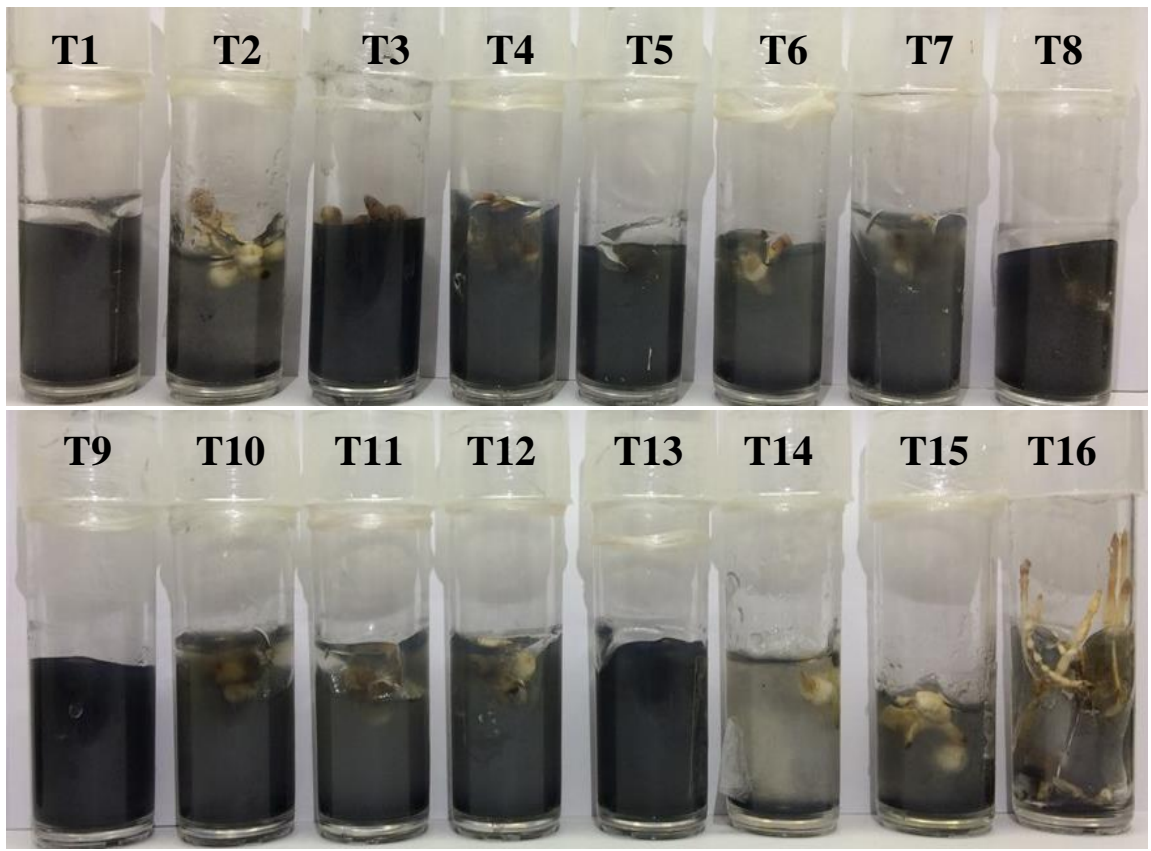

Fig 2. Patterns representative of tissue response in date palm inflorescence according to different 2iP and 2,4-D concentrations (mg/L): T1: 0 2iP + 0 2,4-D; T2: 0 2iP + 50 2,4-D; T3: 0 2iP + 100 2,4-D; T4: 0 2iP + 150 2,4-D; T5: 1.5 2iP + 0 2,4-D; T6: 1.5 2iP + 50 2,4-D; T7: 1.5 2iP + 100 2,4-D; T8: 1.5 2iP + 150 2,4-D; T9: 3.0 2iP + 0 2,4-D; T10: 3.0 2iP + 50 2,4-D;T11:3.0 2iP + 100 2,4-D;T12:3.0 2iP + 150 2,4-D;T13: 4.5 2iP + 0 2,4-D; T14: 4.5 2iP + 50 2,4-D; T15: 4.5 2iP + 100 2,4-D; and T16: 4.5 2iP + 150 2,4-D. 
In the present study, the combinations of concentrations of 2,4-D (150 mg/L) and 2iP (4.5 mg/L) were higher than those traditionally found in scientific literature $(100 \mathrm{mg} / \mathrm{L} \mathrm{2,4-D}$ and $3 \mathrm{mg} / \mathrm{L} 2 \mathrm{iP}$ ). These results suggest that even higher concentrations of these two reagents might be efficient in the micropropagation of new existing date palm genotypes in the Submedium São Francisco River Valley.

\section{Materials and Methods}

\section{Explant sampling and disinfection}

Inflorescence segments containing one or more floral buds were used as explants. These explants were extracted from spathes measuring approximately $20 \mathrm{~cm}$-long, collected from adult female date palm maintained at the State University of Bahia (UNEB). Disinfestation of spathes and inflorescences was performed according to Ribeiro and Teixeira (2017)

\section{In vitro cultivation of inflorescence segments}

Explants were submerged in a culture medium comprised of inorganic MS salts (Murashige and Skoog, 1962), combined with $0.5 \mathrm{mg} / \mathrm{L}$ nicotinic acid, $0.1 \mathrm{mg} / \mathrm{L}$ pyridoxine $. \mathrm{HCl}, 0.1$ $\mathrm{mg} / \mathrm{L}$ tiamine $. \mathrm{HCl}, 40 \mathrm{mg} / \mathrm{L}$ adenine sulphate, $100 \mathrm{mg} / \mathrm{L} \mathrm{i-}$ inositol, $30 \mathrm{~g} / \mathrm{L}$ sucrose, $7 \mathrm{~g} / \mathrm{L}$ agar (Himedia), and $3 \mathrm{~g} / \mathrm{L}$ activated charcoal. The $\mathrm{pH}$ was gauged at $5.7 \pm 0.1$ and charcoal and agar were added after measuring $\mathrm{pH}$.

The medium was sterilized in autoclave for a period of 20 minutes, at a temperature of \pm 121 으 and pressure of $1 \mathrm{kgf}$ $\mathrm{cm}^{-2}$. After preparation, the nutritious medium was distributed in $15-\mathrm{mL}$ aliquots per test tube $(25 \mathrm{~mm} \times 150$ $\mathrm{mm}$ ), covered with polypropylene caps, and cultures were maintained in a dark chamber for approximately four months. After this period, the percentage of explants that responded to the in vitro stimulus in each replicate was measured. Flower bud swelling and callus or root formation were considered explant reactions. Explants that either had no reaction, maintaining their primary initial form or were completely oxidized and dead were discarded.

\section{Experimental design}

The experiment was conducted in an entirely randomized $4 \mathrm{x}$ 4 factorial design, with 4 concentrations of $2 \mathrm{iP}(0,1.5,3$, and $4.5 \mathrm{mg} / \mathrm{L})$ and four concentrations of 2,4-D (0,50,100, and $150 \mathrm{mg} / \mathrm{L}$ ), totaling 16 treatments with five replicates and plots comprised of four test tubes with one explant each. Data were transformed by arch-sine $[\mathrm{V}(\%+0.5 / 100)]$ and submitted to an analysis of variance and polynomial regression, with the help of the Winstat program at the Federal University of Pelotas - RS.

\section{Conclusions}

2,4-D is a synthetic auxin that effectively induces in vitro swelling, callus, or root formation in date palm inflorescence explants. The absence of 2,4-D is more harmful to the in vitro response of date palm inflorescence explants than low $2 \mathrm{iP}$ values. The combination of 2,4-D with a cytokine is important to induce an in vitro response from date palm inflorescence explants. The concentrations of $1.5 \mathrm{mg} / \mathrm{L} \mathrm{2iP}$ combined with $150 \mathrm{mg} / \mathrm{L} \mathrm{2,4-D}$, as well as $3.0 \mathrm{mg} / \mathrm{L}$ 2iP with
$141.36 \mathrm{mg} / \mathrm{L}$ 2,4-D, were effective in inducing in vitro swelling of date palm floral buds. The concentration of 150 $\mathrm{mg} / \mathrm{L} \mathrm{2,4-D}$ combined with $4.5 \mathrm{mg} / \mathrm{L} 2 \mathrm{iP}$ favors in vitro root formation in date palm inflorescence explants via adventitious organogenesis.

\section{Acknowledgments}

We are grateful to Embrapa Semiárido and to the State University of Bahia for their financial support.

\section{References}

Abul-Soade AA, Mahdi SM (2010) Commercial production of tissue culture date palm (Phoenix dactyliferaL.) by inflorescence technique. Journal of Genetic Engineering and Biotechnology. 8:39-44.

Al-Khayri JM (2010) Somatic embryogenesis of date palm (Phoenix dactyliferaL.) improved by coconut water. Biotechnology. 9:477-484.

Aslam J, Khan SA, Cheruth AJ, Mujib A, Sharma MP, Srivastava PS (2011) Somatic embryogenesis, scanning electron microscopy, histology and biochemical analysis at different developing stages of embryogenesis in six date palm (Phoenix dactylifera L.) cultivars. Saudi Journal of Biological Sciences. 18:369-380.

Badhawy EM, Habib AMA, El-Bana A, Yosry G (2005) M. Propagation of date palm (Phoenix dactylifera) plants by using tissue culture technique. Arabian Journal of Biotechnology. 8:343-354.

Bekheet S (2013) Direct Organogenesis of Date Palm (Phoenix dactylifera L.) for Propagation of True-to-Type Plants. Scientia Agriculturae. 4(3):85-92.

Bhaskaran S, Smith RH (1992) Somatic embryogenesis from shoot tip and immature inflorescence of Phoenix dactyliferacv. Barhee. Plant Cell Reports. 12:22-25.

Chawla HS (2004) Introduction to plant biotechnology. 2. ed. Enfield: Science Publishers. $538 \mathrm{p}$.

Costa NM de S, Aloufa, MAl (2010) Influência da luz na germinação in vitro de sementes de tamareira (Phoenix dactyliferaL.). Revista Ciências Agronômicas. 34:16301633.

Eke CR, Akomeah P, Asemota O (2005) Somatic embryogenesis in date palm (Poenix dactylifera L.) from apical meristem tissues from 'zebia' and 'loko' landraces. African Journal of Biotechnology, 4:244-246.

El-Bahr MK, El-Hamid A, Matter MA, Shaltout A, Bekheet SA, El-Ashry AA (2016) In vitro conservation of embryogenic cultures of date palm using osmotic mediated growth agents. Journal of Genetic Engineering and Biotechnology. 14:363-370.

Eldin AFMZ, Ibrahim HA (2015) Some biochemical changes and activities of antioxidant enzymes in developing date palm somatic and zygotic embryos in vitro. Annals of Agricultural Science. 60(1):121-130.

El Hadrami I, Cheikh R, Baaziz M (1995) Somatic embryogenesis and plant regeneration from shoot-tip explants in Phoenix dactylifera L. Biologia Plantarum. 37(2):205-211.

Eshraghi P, Zarghani R, Miraldulbaghi M (2005) Somatic embryogenesis in two Iranian date palm cultivars. Biotechnology. 11:1309-1312.

FAO (2017) Statistical databases. http://faostat.fao.org (access: 01/06/2017) 
Khelil SR, Jardé E, Cabello-Hurtado F, Khelil A, Esnault M (2016) Structure and composition of the wax of the date palm, Phoenix dactylifera L., from the septentrional Sahara. Scientia Horticulturae. 201:238-246.

Khierallah HSM, Bader SM (2007) Micropropagation of Date Palm (Phoenix dactylifera L.) var. Maktoom through Direct Organogenesis. Acta Horticulturae. 736:213-224.

Murashige T, Skoog F (1962) A revised medium for rapid growth and bioassays with tobacco tissue cultures. Physiologia Plantarum. 15:473-497.

Othmani A, Bayoundh C, Drira N, Trifi M (2009) In vitro cloning of date palm Phoenix dactylifera L., cv. Degletbey by using embyogenic suspension and temporary immersion bioreactor (tib). Biotechnol. \& Biotechnol. 23:1181-1188.

Ribeiro JM, Teixeira SL (2017) Clonagem in vitro de tamareira (Phoenix dactylifera L.). Petrolina: Embrapa Semiárido (Embrapa Semiárido. Comunicado Técnico, 170).
Simão, S. Tratado de fruticultura. Piracicaba: FEALQ, 1998. $760 \mathrm{p}$.

Taha HS, Bekheet SA, El-Bahr MK (2003) Alternative approach for micropropagation of the date palm cV. Zaghlool. Arabian Journal of Biotechnology. 6(1):103-112.

Teixeira SL, Ribeiro JM (2015) Influência da concentração de 2iP no meio de cultura, sobre a embriogênese somática em inflorescência de tamareira (Phoenix dactylifera L.). In: SIMPÓSIO DE FRUTICULTURA DO VALE DO SÃO FRANCISCO, 1. 2015, Juazeiro. Resumos. Petrolina: UNIVASF: 2015. p. 380-383.

Zayed EMM, El Din AFMZ, Manaf HH, Abdelbar OH (2016) Floral reversion of mature inflorescence of date palm in vitro. Annals of Agricultural Science. 61(1):125-133.

Zouine J, El Hadrami I (2007) Effect of 2,4-D, glutamine and BAP on embryogenic suspension culture of date palm (Phoenix dactylifera L.). Scientia Horticulturae. 112:221226. 